\title{
境界要素法による静電界および静磁界解析における 未知ベクトル変数の計算精度への影響
}

\author{
正員坪井始 (岡山大) \\ 准員田中始男 (岡山大)
}

\section{Influence of Vector Variables to the Computational Accuracies of Boundary Element Method for Electrostatic and Magnetostatic Problems \\ Hajime Tsuboi, Member, Motoo Tanaka, Associate (Okayama University)}

The applicability of boundary element method has been shown by its applications to scalar potential problems. However, unified formulations for the boundary element method using vector variables and relations between unknown vector variables and the accuracy of the solutions have not been discussed. In this paper, the unified formulation, how to select unknowns and their influence to the accuracy of the solutions in magnetostatics and electrostatics were investigated, and the following results were obtained.

When electric field is assumed as unknown in electrostatic problems, or magnetic flux density or vector potential is assumed as unknown in magnetostatic problems, the formulation for the bound. ary element method using vector variables can be performed. In magnetostatic problems, the equations for the method using a vector potential were shown, and their suitability was verified. Furthermore, in the method using the vector potential as unknown, there is a tendency for computational error of magnetic flux density to larger than the method using magnetic flux density as unknown, and computational error for the numerical integration of magnetic flux density may become large near the boundary surfaces because of its strong singularity.

キーワード : 境界要素法, 静電界解析, 静磁界解析, ベクトル変数, 数值解析

\section{1. まえがき}

電磁界の数值解析法としては, 積分方程式法, 有限 差分法, 有限要素法, 境界要素法などがあり, 各手法 の特長に応じた対象に適用されている(1)(2)。このなか で，境界要素法は，適用が磁気飽和のような非線形性 のない場に限られるが, 必要な入力データ数が少な い, 高精度の解が得られるなどの特長があり, 最初に スカラポテンシャル問題に適用され, その有効性が示 されている(3)。

本論文では, 電磁波の問題に適用されているべクト 儿変数を用いた境界要素法(4)について静電界扝よび静 磁界問題における検討を行う。スカラポテンシャルを
用いた境界要素法 ${ }^{(3)}$ は積分方程式法の一つである表面 荷法との共通点が多い(5)。また，ベクトル変数を用い た境界要素法は，境界積分法 (Boundary Integral Method）(4) と呼ばれているように，積分方程式法， 特に境界積分法から派生した手法と考えられる。静電 界問題は，ソースが電位条件あるいは電荷で与えられ るため，スカラポテンシャル問題として扱うことがで き, 境界要素法による解析手法は確立されている ${ }^{(3)}$ 。 しかし, 磁界問題抢よび電磁界問題は, ベクトル量で ある電流のソースを考える必要があり，べクトル変数 の考慮が不可欠となる。静磁界問題においては, 磁束 密度 (磁界) またはベクトルポテンシャルを末知数と する方法が考えられる。前者については積分方程式法 
との関係が検討され(6), 更に磁束密度と電界を末知数 とする境界要素法が渦電流問題に挔張されてい $ろ^{(7)(8)}$ 。また，ヘクトルポテンシャルを用いた境界要 素法も提案されている(9) (11)。スカラグリーンの定理 を用いた定式化による检討 ${ }^{(12)}$ 䉙界を末知数とする 有限要素法についての検討(13) 当行われているが, べ クトル変数を用いる境界要素法に関する統一的な定式 化の検討, 未知変数の違いの計算誤差への影響など十 分な考察が行われているとは言えない。従って, 本論 文では, 静磁界および静電界問題においてべクトルグ リーンの定理を用いた境界要素法の定式化および外部 条件の与え方などについて考察し, 末知ベクトル変数 が境界要素法に与える影響について計算例を用いて検 討する。

\section{2. 定式 化}

ポテンシャル問題(スカラポテンシャル問題)におけ る境界要素法の定式化はグリーンの定理（以後，べク トルグリーンの定理と区別するためスカラグリーンの 定理と呼ぶを用いて行われ 用的解析手法として種々の分野に応用されている。

しかし，磁界問題および電磁界問題においては，心 クトル量のソースである電流を考える必要があり, 心 クトル変数の考慮が不可欠となる。スカラグリーンの 定理のベクトル類似式は, ベクトルグリーンの定 理 $^{(4)(14)}$ と呼ばれ，ベタトル変数を用いた境界要素法の 基礎となる。

また，静電界および静磁界問題の支配方程式はマク スウェルの方程式から得られるが, 本論文では媒質が 一様で一定な場合を扱うことにする。

〈2・1〉べクトル变数を用いた境界要素法の基本式 ベタトル変数としては, 電界, 磁束密度, ベタトル ポテンシャルなどが考えられるが，ここではべクトル 変数を用いた境界要素法の統一的な基本式を導出 する。

図 1 の領域 $V に$ にいて, $\boldsymbol{P}$ と $\boldsymbol{Q}$ を位置に関する ベクトル変数とし，その一次および二次導関数が閉曲 面 (境界面) $S$ とその内部で連続であるとすると，べ クトルグリーンの定理は次式で与えられる ${ }^{(4)(14)}$ 。

$$
\begin{array}{r}
\iiint_{V}(\boldsymbol{Q} \cdot \nabla \times \nabla \times \boldsymbol{P}-\boldsymbol{P} \cdot \nabla \times \nabla \times \boldsymbol{Q}) d v \\
\quad=\iint_{S}(\boldsymbol{P} \times \nabla \times \boldsymbol{Q}-\boldsymbol{Q} \times \nabla \times \boldsymbol{P}) \cdot \boldsymbol{n}^{\prime} d s
\end{array}
$$

ここで, $V: S$ に囲まれた領域, $\boldsymbol{n}^{\prime}: S$ 上の 外向き単位法線ベクトル

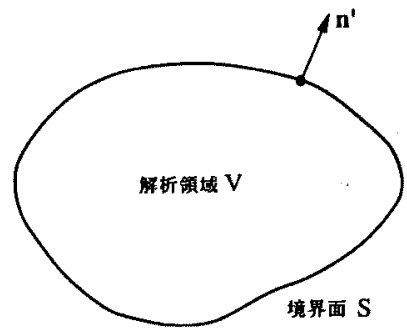

図 1 境界面之解析領域

Fig. 1. Boundary surface and region to be analized.

$S$ 上およびその内部で一次および二次導関数が連続 な任意のベクトル変数を $\boldsymbol{F}$ とし，(1)式において次 のように置く。

$$
\begin{aligned}
& P=F \\
& \boldsymbol{Q}=\phi \boldsymbol{a}
\end{aligned}
$$
基本解は静電界, 静磁界問題では次式で与えられる。 $\phi=\phi\left(x, x^{\prime}\right)$

$$
=\frac{1}{4 \pi\left|x-x^{\prime}\right|}=\frac{1}{4 \pi r}
$$

ここで, $r=\left|x-x^{\prime}\right|, \quad x$ : 計算点の位置べク

トル, $\boldsymbol{x}^{\prime}$ : ソース点の位置ベクトル

(2)式を(1)式へ代入すると次式が得られる。

$$
\begin{aligned}
& \iiint_{V}[(\phi \boldsymbol{a}) \cdot \nabla \times \nabla \times \boldsymbol{F}-\boldsymbol{F} \cdot[\nabla\{\nabla \cdot(\phi \boldsymbol{a})\} \\
& \left.\left.\quad-\nabla^{2}(\phi \boldsymbol{a})\right]\right] d v \\
& \quad=\iint_{S}\{\boldsymbol{F} \times \nabla \times(\phi \boldsymbol{a})-(\phi \boldsymbol{a}) \times \nabla \times \boldsymbol{F}\} \cdot \boldsymbol{n}^{\prime} d s
\end{aligned}
$$

$\boldsymbol{a}$ が定ベタトルであることに注意し，べクトル公式を 用いて (4)式を整理すると次式が得られる。

$$
\begin{aligned}
\iiint_{V}\{\boldsymbol{a} \cdot(\nabla \times \nabla \times \boldsymbol{F}) \phi+\boldsymbol{a} \cdot \nabla \phi(\nabla \cdot \boldsymbol{F}) \\
\left.+\boldsymbol{a} \nabla^{2} \phi \boldsymbol{F}\right\} d v-\iint_{s} \boldsymbol{a} \cdot \nabla \phi\left(\boldsymbol{F} \cdot \boldsymbol{n}^{\prime}\right) d s \\
=\iint_{s}\left\{\boldsymbol{a} \cdot\left(\boldsymbol{n}^{\prime} \times \boldsymbol{F}\right) \times \nabla \phi-\boldsymbol{a} \cdot(\nabla \times \boldsymbol{F})\right. \\
\left.\quad \times \boldsymbol{n}^{\prime} \phi\right\} d s \ldots \ldots \ldots \ldots \ldots \ldots \ldots \ldots \ldots \ldots
\end{aligned}
$$

(4')式において $\boldsymbol{a}$ が任意であることを考慮すると，

(4')式から次式が得られる。

$$
\begin{aligned}
& \iint_{S}\left\{\left(\boldsymbol{F} \cdot \boldsymbol{n}^{\prime}\right) \nabla \phi-\left(\boldsymbol{F} \times \boldsymbol{n}^{\prime}\right) \times \nabla \phi-(\nabla \times \boldsymbol{F})\right. \\
& \left.\quad \times \boldsymbol{n}^{\prime} \phi\right\} d s-\iiint_{V}\{(D \times D \times \boldsymbol{F}) \phi \\
& \quad+(\nabla \cdot \boldsymbol{F}) \nabla \phi\} d v=0 \cdots \cdots \cdots \cdots \cdots \cdots \cdots\left(4^{\prime \prime}\right)
\end{aligned}
$$


計算点 $(x)$ に扔ける演算子Vを、ソース点 $\left(x^{\prime}\right)$ にお ける演算子置で置き換元，特異点積分を行うと計算 点 $i$ （その位置べクトルは $\boldsymbol{x}$ ）における $\boldsymbol{F}$ の式が得 られる(4)(15)。

$$
\begin{aligned}
& \frac{\Omega_{i}}{4 \pi} \boldsymbol{F}_{i} \\
& =\iint_{s}\left\{-\left(\boldsymbol{F} \cdot \boldsymbol{n}^{\prime}\right) \boldsymbol{D}^{\prime} \phi+\left(\boldsymbol{F} \times \boldsymbol{n}^{\prime}\right) \times \nabla^{\prime} \phi\right. \\
& \left.\quad+\left(\nabla^{\prime} \times \boldsymbol{F}\right) \times \boldsymbol{n}^{\prime} \phi\right\} d s+\iiint_{v}\left(\nabla^{\prime} \times \nabla^{\prime} \times \boldsymbol{F} \phi\right. \\
& \left.\quad+\nabla^{\prime} \cdot \boldsymbol{F} \nabla^{\prime} \phi\right) d v \quad \cdots \cdots \cdots \cdots \cdots \cdots \cdots(5)
\end{aligned}
$$

ここて

$$
\nabla^{\prime} \phi=-\nabla \phi=\frac{x-x^{\prime}}{4 \pi\left|x-x^{\prime}\right|^{3}}=\frac{r}{4 \pi r^{3}}
$$

$\Omega_{i}$ 注領域 $V$ を見る立体角で，iが $V$ の内部にあると き $4 \pi ， i$ が $S$ 上にあるとき $2 \pi ， i か ゙ V$ の外部にある とき0となる。

また，(5) 式右辺の体積分の第 1 項は次のように書 ける。

$$
\begin{aligned}
& \iiint_{V} \nabla^{\prime} \times \nabla^{\prime} \times \boldsymbol{F} \phi d v \\
& =\iiint_{V}\left(\nabla^{\prime} \times\left(\phi \nabla^{\prime} \times \boldsymbol{F}\right)-\nabla^{\prime} \phi \times \nabla^{\prime} \times \boldsymbol{F}\right\} d v \\
& =-\iint_{S}\left(\nabla^{\prime} \times \boldsymbol{F}\right) \times \boldsymbol{n}^{\prime} \phi d s+\iiint_{V}\left(\nabla^{\prime} \times \boldsymbol{F}\right) \\
& \quad \times \nabla^{\prime} \phi d v
\end{aligned}
$$

従って，(5)式は次のように書ける。

$$
\begin{aligned}
\frac{\Omega_{i}}{4 \pi} \boldsymbol{F}_{i}= & \iint_{s}\left\{-\left(\boldsymbol{F} \cdot \boldsymbol{n}^{\prime}\right) \nabla^{\prime} \phi+\left(\boldsymbol{F} \times \boldsymbol{n}^{\prime}\right)\right. \\
& \left.\times \nabla^{\prime} \phi\right\} d s+\iiint_{V}\left\{\left(\nabla^{\prime} \times \boldsymbol{F}\right)\right. \\
& \left.\times \nabla^{\prime} \phi+\nabla^{\prime} \cdot \boldsymbol{F} \nabla^{\prime} \phi\right\} d v
\end{aligned}
$$

(5)式または (6)式がベクトル変数を用いる境界要 菜法の基本式である。雨式において面積分は境界面 $S$ の外のソースの寄与を表し, 体積分は $V$ 内のソース の寄与を表す ${ }^{(12)}$ 。

(5)式は $\nabla \times \nabla \times F$ 項が陽に現れているためべク トルポテンシャルのように2 階の回転演算で支配方程 式が表される場合に適用され，(6)式はマクスウェル の方程式のように1階の微分方程式が支配方程式の場 合に適用される。ここで，(6)式が基礎的なべクトル 変数を用いた境界要素法の基本式と考えることができ る。（6)式に扔いて境界面 $S$ をの影響がなくなる 無限遠にとるならば，ベクトル $F$ がその回転と発散 の体積分で決まる式となる。このことは，べクトル場 が回転と発散が与えられれば一義的に決まるという数

奄学論A，110 巻 4 号，平成 2 年
学的な定義に符合している。従って，(5)式はべクト ル変数の支配方程式に応じた $(6)$ 式の一つの変形であ る。以下の節では，このような観点から磁束密度，べ クトルポテンシャル，電界を未知ベクトル変数とする 境界要素法の基本式について検討する。

〈2・2〉磁束密度を用いた境界要素法 静磁界問 題を解くために，未知バクトル変数として磁束密度 $\boldsymbol{B}$ を用いる場合を考える。支配方程式は，マクスウ エルの方程式より次式で表される。

$$
\begin{aligned}
& \nabla \times(B / \mu)=\boldsymbol{J} \\
& \nabla \cdot B=0 \\
& \frac{\Omega_{1}}{4 \pi} B_{i}=\iint_{s}\left(-\left(B \cdot n^{\prime}\right) \nabla^{\prime} \phi+\left(B \times n^{\prime}\right)\right. \\
& \left.\times \nabla^{\prime} \phi\right\} d s+\iiint_{V} \mu \boldsymbol{J} \times \nabla^{\prime} \phi d v
\end{aligned}
$$

そこて，F=Bとして，(7)，(8)式を(6)式人

（9）式に招いて, $\boldsymbol{B} \cdot \boldsymbol{n}^{\prime}$ は表面磁荷に, $\boldsymbol{B} \times \boldsymbol{n}^{\prime}$ は表 面電流に対応し(6)，右辺の体積分はビオサバールの法 則による電流の磁束密度への寄与を表している。すな わち, 境界面 $S$ を無限遠に遠ざけたとき，その奇与 は零となり，(9)式はビオサバールの法則の式とな る。二媒質問題の場合は，(9)式加ら得られる境界面 の表裏の式を用いて，B・的または $\boldsymbol{B} \times \boldsymbol{n}^{\prime}$ を消去する ことができ，表面磁荷法または表面電流法の式がそれ ぞれ得られる ${ }^{(6)}$ 。こことは，(9)式は境界面 $S に$ 囲まれた閉領域の式であるが，開領域の式である積分 方程式の式と等価な式であることを示している。文献 （14）に扔いて，(9)式の各項の物理的な意味について 檢討され，(9)式が $(7) ，(8)$ 式を满たすことが示さ れている。

図 2 に示す境界面 $S$ 上の計算点 $i$ に抢ける磁束密

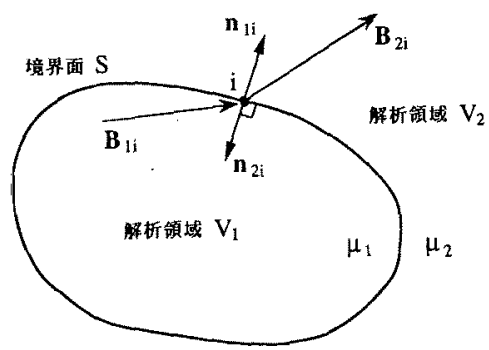

図 2 境界面 $S$ で区切られた二つの解析領域

Fig. 2. Two regions divided by surface $S$. 
度 $\boldsymbol{B}$ の境界条件は, 磁束密度の法線成分と磁界の接 線成分の連続条件を用いて次式で表される。

$$
\left.\begin{array}{l}
\boldsymbol{B}_{1 i} \cdot \boldsymbol{n}_{\mathbf{1 i}}=\boldsymbol{B}_{2 i} \cdot \boldsymbol{n}_{1 i} \\
\left(\boldsymbol{B}_{1 i} \times \boldsymbol{n}_{1 i}\right) / \mu_{1}=\left(\boldsymbol{B}_{2 i} \times \boldsymbol{n}_{1 i}\right) / \mu_{2}
\end{array}\right\}
$$

ここで， $\boldsymbol{B}_{1}, \boldsymbol{B}_{2}$ ：それぞれ境界面 $S$ における 領域 $V_{1}, V_{2}$ 側の磁束密度， $\mu_{1}, \mu_{2}$ : それぞれ 領域 $V_{1}, V_{2}$ の透磁率, $n_{1}: S$ 上で $V_{1}$ から $V_{2}$ へ向かう単位法線ベクトル

(9) 式において, $\boldsymbol{B}_{i}=\boldsymbol{B}_{1 i}, \boldsymbol{n}^{\prime}=\boldsymbol{n}_{\mathbf{1}}^{\prime}, \Omega_{i}=2 \pi$ とし て $S$ 上で $V_{1}$ 側の式を, $\boldsymbol{B}_{i}=\boldsymbol{B}_{2 i}, \quad \boldsymbol{n}^{\prime}=\boldsymbol{n}_{2}^{\prime}, \quad \Omega_{i}=2 \pi$ として $V_{2}$ 側の式を $N$ 個の節点において作成すると 次式が得られる。

$$
\begin{aligned}
& \frac{1}{2}[I]\left\{B_{1}\right\}=\left\{C_{10}\right]\left\{B_{1}\right\}+\left\{B_{1 o}\right\} \\
& \frac{1}{2}[I]\left\{B_{2}\right\}=\left[C_{2 o}\right]\left\{B_{2}\right\}+\left\{B_{2 o}\right\}
\end{aligned}
$$

ここで, $[I]: 3 N \times 3 N$ の単位行列, $\left[C_{10}\right]$, $\left\{C_{2 o}\right]: 3 N \times 3 N$ の係数行列, $\left\{B_{1}\right\},\left\{B_{2}\right\}:$ 末 知磁束密度 (3N 次), $\left\{B_{10}\right\},\left\{B_{20}\right\}$ : 電流な どの境界面以外のソースによる磁束密度 ( $3 N$ 次)

また，(11)式において $\left\{B_{1}\right\},\left\{B_{10}\right\},\left\{B_{2}\right\},\left\{B_{20}\right\}$ は次 式で表される。

$$
\begin{aligned}
& \left\{B_{1}\right\}=\left\{\begin{array}{llllll}
B_{1 n 1} & B_{1 u 1} & B_{1 v 1} & B_{1 n 2} & B_{1 u 2} & B_{1 v 2} \cdots
\end{array}\right\}^{T} \\
& \left\{B_{10}\right\}=\left\{B_{1 \text { ond }} B_{1 \text { oul } 1} B_{1 \text { ov } 1} \ldots \ldots \ldots \ldots \ldots \ldots\right\}^{T} \\
& \left\{B_{2}\right\}=\left\{\begin{array}{lll}
B_{2 n 1} & B_{2 u 1} & B_{2 v 1}
\end{array}\right. \\
& \left\{B_{2 o}\right\}=\left\{B_{2 o n 1} B_{2 o u 1} B_{2 o v 1}\right.
\end{aligned}
$$

(12)式において，nは法線方向，uとvはそれぞれ 互いに垂直な接線方向を表す添字である。

(11 a)，(11b)式は独立な二組の式の形であるが, (10)式より図 2 に示す境界面上の点 $i$ に扔沙る次の条 件によって関係づけられている。

$$
\left.\begin{array}{l}
B_{1 n i}=B_{2 n i} \\
\frac{1}{\mu_{1}} B_{1 u i}=\frac{1}{\mu_{2}} B_{2 u i} \\
\frac{1}{\mu_{1}} B_{1 v i}=\frac{1}{\mu_{2}} B_{2 v i}
\end{array}\right\}
$$

(13)式において，一方の側のB $B$ 末知数として図 2 に示吉境界面上の点 $i て(11 \mathrm{a}) ，(11 \mathrm{~b})$ 式を用いて 式を組立てれ稵，磁束密度の各成分を未知数とする最 終的な $3 N$ 次の連立方程式を作成することができる。

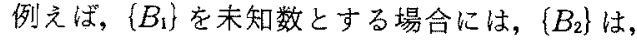
(13)式より

$$
\left\{B_{2}\right\}=\left\{B_{1 n 1} \frac{\mu_{2}}{\mu_{1}} \dot{B}_{1 u 1} \frac{\mu_{2}}{\mu_{1}} B_{1 v 1} \cdots \cdots\right\}^{T}
$$

と表される。これを(11b)式に代入して $\left\{B_{2}\right\} を\left\{B_{1}\right\}$ で置き換えると次のようになる。

$\frac{1}{2}[I]^{\prime}\left\{B_{1}\right\}=\left[C_{20}\right]^{\prime}\left\{B_{1}\right\}+\left\{B_{2 o}\right\}$

ここで，[I $]^{\prime}:[I]$ の接線成分に対応する对 角項を $\left(\mu_{2} / \mu_{1}\right)$ 倍した行列, $\left[C_{20}\right]^{\prime}:\left[C_{20}\right]$ の 接線成分に対応する列を $\left(\mu_{2} / \mu_{1}\right)$ 倍した行列

(11 a) 式と (11 b') 式を加えると次式が得られる。

$$
\begin{aligned}
& \frac{1}{2}\left([I]+[I]^{\prime}\right)\left\{B_{1}\right\} \\
& \quad=\left(\left[C_{10}\right]+\left[C_{2 o}\right]^{\prime}\right)\left\{B_{1 i}\right\}+\left\{B_{10}\right\}+\left\{B_{20}\right\}
\end{aligned}
$$

(14)式は，計算点 $i に$ にいて，まず $V_{1}$ 側で式を立 てそれに加えて $V_{2}$ 側の立てたものである。これ は，節点法において接続されたインピーダンスごとに 隣接節点との関係式を作成し，係数マトリックスに加 えていく過程と類似している。（13）式を整理して，次 のような形式の $3 N$ 元の連立方程式を作成できる。

$\{C]\{B\}=\{d\}$

ここで, $\{C\} ：$ 最終方程式の係数行列,

$\{B\}$ : 未知磁束密度ベクトル, $\{d\}$ : 最終方

程式の定数ベクトル

(11 b) 式の任意の行を定数倍して (14)式の任意の行 に加えても, 行列の性質から (15) 式の解は変わらない 加，最終方程式を組立てる際には，誤差が入りにく くなるへく簡単な形になるように(11b)式の各行を 任意の定数倍して $(11 \mathrm{a})$ 式に加えることができる。

境界面 $S$ は, ベクトルグリーンの定理の前提条件 を満たせば，任意に選べるが，一様な媒質中に設定す ることは無意味である。すなわち，(13)式においてす ベての成分が連続になるため $\left(\mu_{2} / \mu_{1}\right)=1$ となり, $n_{2 i}$ $=-n_{1 i}$ であることに注意すれば，(11 a)式に(11 b) 式を加えて(14)式注，

$$
\left\{\boldsymbol{B}_{\mathbf{1 i}}\right\}=\left\{\boldsymbol{B}_{10}\right\}+\left\{\boldsymbol{B}_{2 o}\right\}
$$

となり, 境界樻分によって得られる $\left[C_{10}\right],\left[C_{20}\right]$ のマ トリックスは消滅する。(16)式は，任意の計算点iの 磁束密度が外部強制項(例えば，ビオサバールの法則） のみで決まることを表しておうり，境界面の設定した意 昧はない。

以上により，境界面のどちらかの面上の磁束密度を 末知ベクトル変数として連立方程式を作成し, 解くこ とができる磁束密度を末知べクトル变数とする境界要 䒺法が示された。任意点の磁束密度は，(9)式により 求められる。また，ビオサバールの式による電流の影 
響のほかに，外部磁界として $\boldsymbol{B}_{0}$ が与えられる場合は (9)式の右辺に $\boldsymbol{B}_{0}$ を加えることができる。

また，ほかにベクトルグりーンの定理による磁界の 式を用いた境界要素法 ${ }^{(16)}$ の提案があるが, 文献(16) では媒質中の電磁界の性質を用いて最終的には表面電 流や表面磁荷についての積分方程式に変換している。

〈2・3〉 ベクトルポテンシャルを用いた境界要素法

次に，末知ベクトル変数としてべクトルポテンシャ ル $\boldsymbol{A}$ を用いた境界要素法による静磁界解析を考える。 静磁界問題の支配方程式は，(7)，（8)式で表される が,ここで, ベクトルポテンシャル $A$ を導入すると, $A$ は，次式で定義される。

$$
\nabla \times A=B
$$

(17)式を(7)式へ代入すると, 次の $A$ の支配方程式 が得られる。

$$
\nabla \times \nabla \times A=\mu \boldsymbol{J}
$$

また，(17)式を(8)式へ代入すると，

$$
\nabla \cdot(\nabla \times A)=0
$$

となり，（8)式はべクトル演算の性礩により常に成立 する。

$A$ のゲージとし，ローレンッゲージを採用すると，

$$
\nabla \cdot A=0
$$

となり，これは静磁界問題ではクーロンゲージに一致 する。

$\boldsymbol{F}=\boldsymbol{A}$ として, (18), (20) 式を(5)式へ代入すると,

$$
\begin{aligned}
& \frac{\Omega_{i}}{4 \pi} \boldsymbol{A}_{i} \\
& =\iint_{S}\left\{-\left(\boldsymbol{A} \cdot \boldsymbol{n}^{\prime}\right) \nabla^{\prime} \phi+\left(\boldsymbol{A} \times \boldsymbol{n}^{\prime}\right) \times \nabla^{\prime} \phi\right. \\
& \left.\quad+\left(\nabla^{\prime} \times \boldsymbol{A}\right) \times \boldsymbol{n}^{\prime} \phi\right\} d s+\iiint_{V} \mu \boldsymbol{J} \phi d v
\end{aligned}
$$

(21)式は, 領域 $V$ 内のベクトルポテンシャル $\boldsymbol{A}$ が, 境界面 $S$ 上の $A$ と $\nabla^{\prime} \times \boldsymbol{A}$ の接線成分によって決ま ることを表している。右辺の体積分の項はべクトルポ テンシャルに対するビオサバールの法則による電流の 奇与を表し， $S$ が無限遠に遠ざかるとき $(9)$ 式の場合 と同样に(21)式はビオサバールの法則を表す。

計算点 $i$ の磁束密度 $\boldsymbol{B}_{i}$ は，(21) 式で表されるべク トルポテンシャルから両辺の回転演算を行って次のよ うに求められる。

$$
\begin{aligned}
\frac{\Omega_{i}}{4 \pi} \boldsymbol{B}_{i}= & \frac{\Omega_{i}}{4 \pi}\left(\nabla \times \boldsymbol{A}_{i}\right) \\
= & -\iint_{S}\left[\left\{\left(\boldsymbol{A} \times \boldsymbol{n}^{\prime}\right) \cdot \nabla\right] \dot{\boldsymbol{V}}^{\prime} \phi\right. \\
& \left.+\left\{\left(\nabla^{\prime} \times \boldsymbol{A}\right) \times \boldsymbol{n}^{\prime}\right\} \times \nabla \phi\right] d s
\end{aligned}
$$

$$
+\iiint_{V} \mu \boldsymbol{J} \times D \phi d v
$$

(22)式を用いれば，境界面上での数值微分 ${ }^{(17)}$ は不要 である。

境界面 $S$ 上の計算点 $i$ における(21)式のための境 界条件は，バクトルポテンシャルの連続条件と磁界の 接線成分の連続条件で，次式で与竞られる。

$$
\begin{aligned}
& \left.\begin{array}{l}
A_{1 n i}=A_{2 n i} \\
A_{1 u i}=A_{2 u i} \\
A_{1 v i}=A_{2 v i}
\end{array}\right\} \text {. } \\
& \left(\nabla^{\prime} \times \boldsymbol{A}\right)_{1 u i} / \mu_{1}=\left(\nabla^{\prime} \times \boldsymbol{A}\right)_{2 u i} / \mu_{2} \\
& \left(\nabla^{\prime} \times \boldsymbol{A}\right)_{1 v i} / \mu_{1}=\left(\nabla^{\prime} \times \boldsymbol{A}\right)_{2 v i} / \mu_{2}
\end{aligned}
$$

磁束密度を用いた場合と同樣に，(21)式を境界面の 両側に適用し，(23)式を用いることによって，一節点 あたりべクトルポテンシャル三成分に対する三つの方 程式を作成することができる。また，(22)式を境界面 の両側に適用し，(24)式を用いることにより，磁束密 度の接線成分二成分に対する二つの方程式を作成する ことがでさる。従って，一つの節点に対して未知数が 五成分で, 方程式が五つとなり, 解くべき連立方程式 を組立てることができる。

一つの節点に対する未知数の数が, 磁束密度を用い る場合は 3 で，この場合は 5 となり不利になるように 思われるが，二媒質問題では (21)，(23)式から作られ るべクトルポテンシャルの式から， $\left(\nabla^{\prime} \times A\right) \times n$ の項 を消去することができるため, べクトルポテンシャル 三成分で連立方程式を作成でき，大きな不利とはなら ない。このとき， $\left(\nabla^{\prime} \times A\right) \times n^{\prime}$ は，得られた $A$ を用 いて磁束密度二成分の連立方程式を作成して, 求める ことができる具体的には， $n^{\prime} の$ 符号に注意して， $V_{1}$ 側で作成した (21) 式に $\mu_{1} / \mu_{2}$ をかけて， $V_{2}$ 側で作 成した(21) 式に加えることによって $\left(\nabla^{\prime} \times A\right) \times n^{\prime} の$ 項を消去することができる。

磁束密度を用いる場合と同様に，外部べクトルポテ ンシャルとして $A_{0} を(21)$ 式の右辺に加えることがで きる。この場合, 通常 $A_{0}$ 注ある磁束密度 $B_{0}$ を表す ように与光るため，次の二つの式を满たす必要がある。

$$
\begin{aligned}
& \nabla \times A_{0}=B_{0} \\
& \nabla \cdot A_{0}=0
\end{aligned}
$$

以上により，ベクトルポテンシャルを末知ベクトル 变数とする静磁界問題のための境界要素法が示さ れた。

また，ベクトルポテンシャルを用いた定式化は, 成 分ごとにスカラ関数としてスカラグリーンの定理を用 いて行うこともできる゙ ${ }^{(9)(13)}$ が，ここでは統一的に心゙ 
クトルグリーンの定理を用いる場合について検討 する。

〈2・4〉 静電界問題 静電界問題の支配方程式は, マクスウェルの方程式より，電界を $\boldsymbol{E}$ として次式で 表される。

$$
\begin{aligned}
& \nabla \times \boldsymbol{E}=0 \\
& \nabla \cdot(\varepsilon \boldsymbol{E})=\rho
\end{aligned}
$$

ここで, $\varepsilon:$ 誘電率, $\rho:$ 電荷密度

静電界問題は, スカラポテンシャル $\psi$ を導入して

$$
\boldsymbol{E}=-\nabla \psi
$$

と扔くことにより， $\nabla \times \boldsymbol{E}=0$ は恒等的に成立するた め, (7b)式より $\nabla^{2} \psi=-\rho / \varepsilon$ なるポアソンの方程式を 解く問題に帰着させることができる。そのため, 静電 界問題は一般に, 積分方程式法の一つである表面電荷 法(18)やスカラポテンシャルを用いた境界要素法 ${ }^{(3)}$ を用 いて解かれている。

一方，(6)式よりポテンシャルを用いないで直接電 界 $\boldsymbol{E}$ を求めることもできる。 $\boldsymbol{F}=\boldsymbol{E}$ として，(27a）, (27b)式を代入すると，次式が得られる。

$$
\begin{aligned}
\frac{\Omega_{i}}{4 \pi} \boldsymbol{E}_{i}= & \iint_{S}\left\{-\left(\boldsymbol{E} \cdot \boldsymbol{n}^{\prime}\right) \nabla^{\prime} \phi+\left(\boldsymbol{E} \times \boldsymbol{n}^{\prime}\right)\right. \\
& \left.\times \nabla^{\prime} \phi\right\} d s+\iiint_{V} \frac{\rho}{\varepsilon} \nabla^{\prime} \phi d v
\end{aligned}
$$

$S$ を無限遠に遠ざけると， $\nabla^{\prime} \phi \rightarrow 0, \phi \rightarrow 0$ となり，

$$
\boldsymbol{E}_{i}=\frac{1}{4 \pi \varepsilon} \iiint_{v} \frac{\rho r}{r^{3}} d v
$$

が得られ, クーロンの法則より求めた電界の式に一致 する。(29)式は静磁界問題の $\boldsymbol{B}$ の式によく対応して おり，ソースが $\nabla \cdot \boldsymbol{E}=\rho / \varepsilon_{0}$ で与えられるか, $\nabla \times \boldsymbol{B}$ $=\mu \boldsymbol{J}$ で与えられるかの違いがあるのみである。

\section{3. 計 算 例}

ベクトル変数を用いた境界要素法を, 理論解のわか つている磁性球モデルおよび三次元モデルとして磁性 立方体モデルに適用し，ここで考察した定式化の妥当 性を確認した。ここでは静磁界問題を扱ったが(9)式 の体積分の值として外部磁束密度を与える問題である ので，この值を(29) 式の体積分で置き換え, 磁束密度 を電界に置き換えれば、ここでの議諭はすべて静電界 問題にも適用することができる。

〈3・1〉磁性球モテル 図 3 に示す半径 $0.1 \mathrm{~m}$ の 磁性球を $\boldsymbol{B}=(0,0,1)$ の一様磁界中に置いたモデルを 用いて，磁束密度を未知ベクトル変数とした場合（ $B$ 法と呼ぶ）とベクトルポテンシャルを末知ベクトル変 数とした場合（ $A$ 法と呼ぶ）の計算の比較を行った。 このとき, 外部磁束密度 $\boldsymbol{B}_{0}$ は $B$ 法では (9) 式の体積

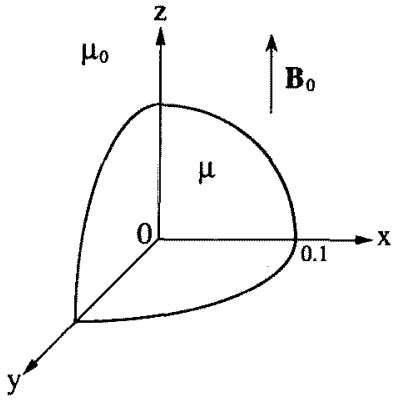

\begin{tabular}{|c|c|c|c|c|c|c|c|}
\hline & \multicolumn{4}{|c|}{$A$ 法 } & \multirow{2}{*}{\multicolumn{3}{|c|}{$\frac{B \text { 法 }}{\begin{array}{c}\text { 磁束密度の㶽差 } \\
(\%)\end{array}}$}} \\
\hline & \multicolumn{3}{|c|}{$\begin{array}{c}\text { 酳束密度の誤差 } \\
(\%)\end{array}$} & \multirow{2}{*}{ 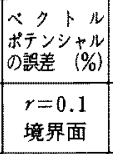 } & & & \\
\hline & $r=0$ & $r=0.05$ & $\begin{array}{l}r=0.1 \\
\text { 境界面 }\end{array}$ & & $r=0$ & $r=0.05$ & $\begin{array}{l}r=0.1 \\
\text { 境界面 }\end{array}$ \\
\hline$\mu_{s}=10$ & -3.48 & -3.80 & -10.7 & -3.27 & -0.680 & -0.720 & -8.17 \\
\hline$\mu_{s}=100$ & -4.42 & -4.76 & -13.8 & $-4,49$ & -0.782 & -0.850 & -8.79 \\
\hline$\mu_{s}=1,000$ & -4.54 & -4.88 & -14.4 & -4.67 & -0.835 & -0.902 & -10.4 \\
\hline
\end{tabular}

図 3 磁性球モデル

Fig. 3. Magnetic sphere model.

表 1 磁性球モデルの計算誤差

Table 1. Computation errors of the mag. netic sphere model.

分の值として与え， $A$ 法では後述するようにその回 転が $B_{0}$ となるような外部べクトルポテンシャル $A_{0}$ を(21)式の体積分の值として与える。三角形要素とし ては平面要素を用い, 要素上の未知ベクトルは一定と する，いわゆる一定要素を用いた。このとき，要素上 に一つの節点を置き，節点で境界条件が成立するよう に方程式を作成している。また，境界積分はすべて数 值積分によって行った ${ }^{(19)}$ 。

対称性を考慮し，球面の $1 / 8$ を 100 の三角形要素に 分割し， $\mu_{s}=10,100,1,000$ とした場合について, $A$ 法と $B$ 法に上る球内部の $z=0$ の平面上, $r=0,0.05$, 0.1 の計算誤差を表 1 亿示す。また， $z$ 軸上の磁束密 度の分布を図 4 に示す。 $z$ 軸上の磁束密度は $z$ 成分の みをもつので, 磁束密度の值は $z$ 成分の大きさに等 しくなっている。計算精度は， $B$ 法のほうが 1 けた 良くなっている。これは，B法に扔いては磁束密度 の接線成分 $B_{t}$ は $z=0$ の平面上で最大に, $z=0.1$ の 上部で零となり, 法線成分 $B_{n}$ は $z=0$ の平面上で票 に, $z=0.1$ の上部で最大となるため, $B_{t}$ と $B_{n}$ が相 補の関係にあって計算精度が高くなっていると思われ る(6)。このことは, 表 1 に㧊いて，末知べクトルであ る $r=0.1$ の磁束密度（接線成分のみである）の精 度に比べて, 内部の磁束密度の精度が非常に良くなっ 


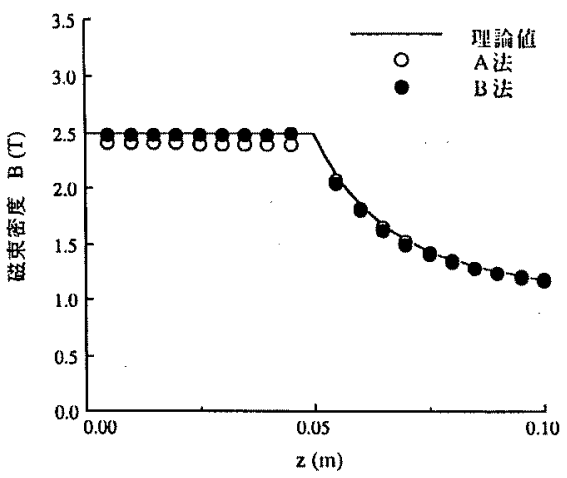

(a) $\mu_{s}=10$

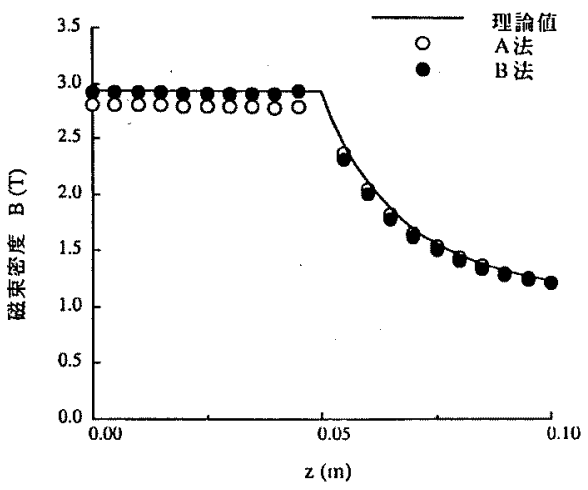

(b) $\mu_{s}=100$

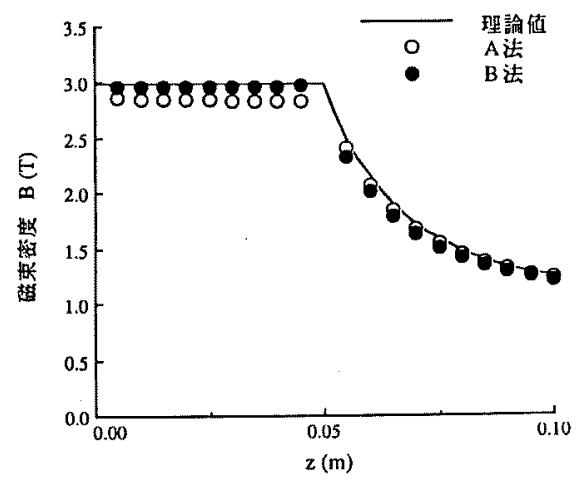

(c) $\mu_{s}=1,000$

図 $4 \quad z$ 軸上の磁束密度分布

Fig. 4. Distributions of magnetic flux density on $z$-axis.

ていることからも類推できる。

一方， $A$ 法の場合は，未知ベクトルである $r=0.1$ のベクトルポテンシャルの精度に比べて, 磁束密度の 接線成分の計算精度が低い。これは，B法のような 相補効果がなく，解析的ではあるが求められたべクト
ルポテンシャルの計算点における微分演算によって磁 束密度を求めるために精度が低くなったものと考えら れる。

また，図 4, 表 1 から明らかなように，比透磁率が 大きくなると， $A$ 法の計算精度が低下している。こ れは，(21），(24)式に示されるように磁束密度の境界 条件として， $A$ 法では磁束密度の接線成分のみが使 用されるため，表面電流法 ${ }^{(6)} に$ 似た性質となっている ためと思われる。このときの誤差の原因は，(24)式で 一方の透磁率が大きくなったときに起きる情報落ちで ある。 $B$ 法では前述の $B_{t}$ と $B_{n}$ の相補の関係によっ て情報落ちの影響が小さくなっていると考えられる。

$A$ 法では, 外部磁束密度 $B_{0}$ を考慮するために, 外 部ベクトルポテンシャル $A_{0}$ を導入し, $\boldsymbol{B}_{0}=(0,0,1)$ として (25)，(26)式を満たすように決定する必要があ る。ここでは

$$
A_{0}=\left(-\frac{y}{2}, \frac{x}{2}, 0\right)
$$

を与えている。この場合の境界面上（球面上）の未知 ベクトル変数, 寸なわちべクトルポテンシャルと磁束 密度の接線成分の分布を図 5 に示す。また，(25)， (26)式を満たす他の $\boldsymbol{A}_{0}$ を与えた場合も同様の解が得 られる(20)。

〈3・2〉磁性立方体モデル 図 6 に示す静磁界問 題用電気学会モデルを簡略化した磁性立方体モデルに $A$ 法と $B$ 法を適用し，その結果を检討した。この場 合も対称性を考慮して，立方体表面の $1 / 8$ を 384 の要 素に分割している。磁性体の比透磁率 $\mu_{\mathrm{s}}$ は 10,100 , 1,000 とした。

$z=0$ の平面上の $y=x$ の直線 $l_{1}$ 上扝よび $z=0.075$ の平面上の $y=x$ の直線 $l_{2}$ 上の磁束密度の分布を図 7 に示す。同図に示すように，磁性体の外部では $A$ 法 と $B$ 法の計算結果はよく一致しているが，内部では 若干の差がある。これは，磁性体球モデルで検討した ように $A$ 法の精度が低下しているためと考えられる。 また, 磁性体内部の境界付近で $A$ 法の磁束密度が大 きくなっているのは，(22)式によって境界面上のべク トルポテンシャルから磁束密度を計算するため, 数值 積分における特異性の強い $1 / r^{4}$ の項の影響である。 特に $M_{s}$ が大きくなるとこの傾向が強くなっている。 このように，同じ精度の数值積分を行った場合， $B$ 法に比べて $A$ 法の磁束密度の計算精度は境界付近て 低下することがわかる。特に，本モデルの場合，角点 の内部でこの傾向が強くなることを示している。図 8 に磁性立方体モデルの $\mu_{\mathrm{s}}=1,000$ のときの磁束密度分 布を示す。同図では，磁束密度べクトルの基点は， 


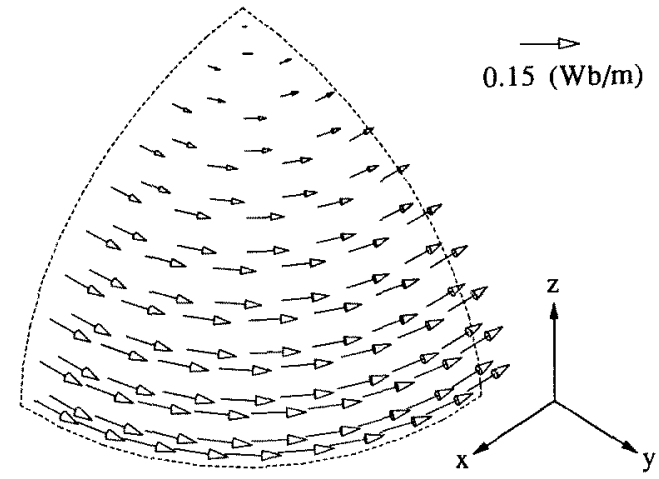

(a) ベクトルポテンシャル

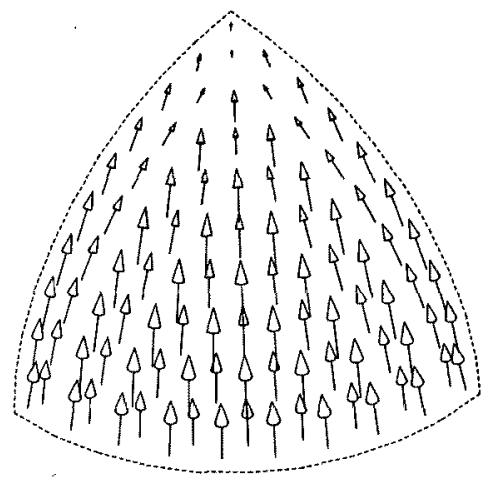

(b) 距束密度の接線成分

図 5 境界面上のベクトルポテンシャルと磁束密度の接線成分

Fig. 5. Vector potentials and magnetic flux densities on the bounary.

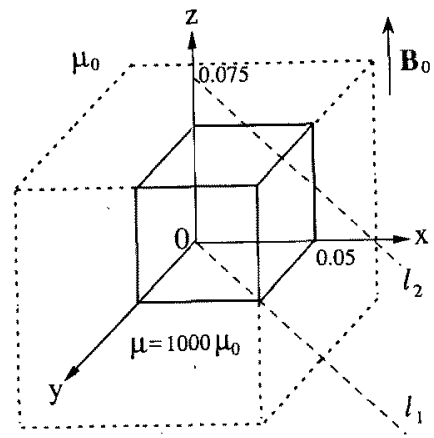

図 6 磁性立方体モデル

Fig. 6. Manetic cube model.

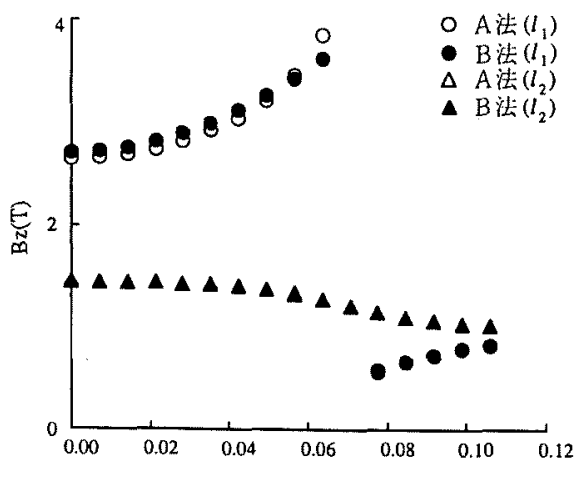

(a) $\mu_{s}=10$
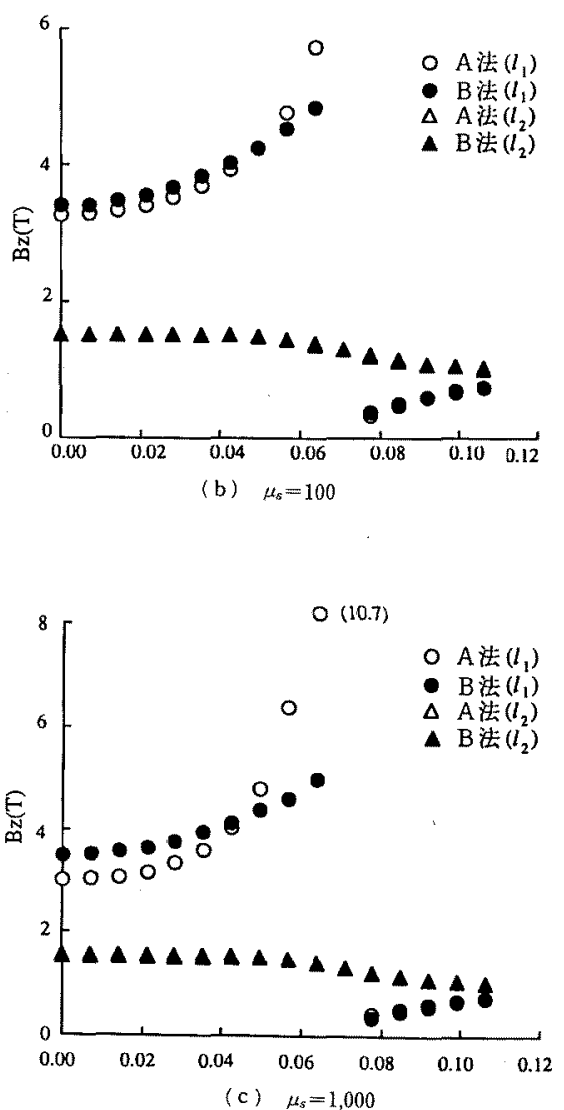

図 7 直線 $l_{1}, l_{2}$ 上の磁束密度分布

Fig. 7. Distributions of magnetic flux density on the lines $l_{1}$ and $l_{2}$. 


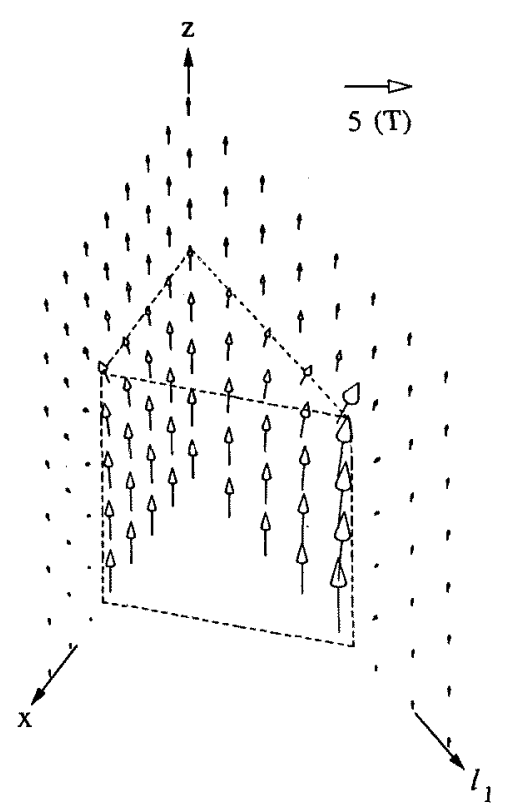

図 8 磁性立方体モデルの磁束密度分布

Fig. 8. Distribution of magnetic flux density of the magnetic cube model.

$y=0$ ( $x$ 軸の上方), $y=x$ (直線 $l_{2}$ の上方) 0 平面上 に等間隔に配置している。

ニつのモデルの計算結果より，バクトル変数を用い た境界要素法の定式化の妥当性を確認することができ た。 $A$ 法， $B$ 法ともほほ同様の結果が得られるが, 境界上のベクトルポテンシャルによる式の微分演算で ある回転演算によって磁束密度を求める $A$ 法では, 直接磁束密度を求める $B$ 法に比べて精度が低下する 傾向があることがわかった。

\section{4.むすび}

以上のように，静磁界，静電界解析のためのバクト ル変数を用いた境界要素法の定式化を示すと共に，末 知ベクトル変数が解の精度に与える影響について検討 した。結果をまとめると次のようになる。

（1）べクトル変数を用いた境界要素法の統一的な 定式化を，ベクトルグリーンの定理を用いて示した。 このとき, ベクトル変数を磁束密度, ベクトルポテン シャル，電界と置くことにより，静磁界または静電界 解析のための定式化を行うことができ，ビオサバール の法則やクーロンの法則による界に矛盾しないことを 示した。

（2）ベクトルポテンシャルを用いた場合には，得
られた境界上のベクトル変数から任意点の磁東密度の 計算を行うには，バクトルポテンシャルの解析的な回 転演算によって得られた式を用いればよいことを示し た。また，外部からの強制項となる外部べクトルポテ ンシャルの選択には任意性があるが，基本式を満たし ていれば妥当な解が得られることを示した。

（3）静磁界解析における，直接磁束密度を用いる 手法とベクトルポテンシャルを用いる手法は，ほほ同 様の結果を与えるが，べクトルポテンシャルを用いる 手法では，境界条件の導入の際の情報落ちのため，お よび求められた境界值による式の微分演算によって磁 束密度を計算するため，計算精度が低下する傾向があ ることがわかった。また，このとき特異性が強くなる ため，境界面付近の数值積分には注意を要することが わかった。特に，透磁率の差が大きいほど，計算精度 の低下が著しいことがわかった。

準定常問題, 過渡応答問題においては, ベクトル変 数を用いることが不可欠となり，磁束密度と電界を用 いる手法㧍よびべクトルポテンシャルとスカラポテン シャルを用いる手法が考えられ，今後の検討が必要で ある。

(平成元年 3 月 27 日受付, 同 2 年 1 月 10 日再受付)

\section{文献}

（1）毛閆：「小特集 電気暼子機器に扔引る計算機支援解析技術 II. 電磁機器の解析技術, A.電界の解析技術」, 電学誌, 108, 209 (昭 63-3)

（2）中田：「小特集 電気電子機器における計算機芚援解析技 街，II，電磁機器の解析技街，B，磁界の解析技街」，同上， $108,213($ 昭 63-3)

（3）C.A.ブレビア：境罳要素法の基程と五用, p.21（昭 56） 培風餙

(4) A. J. Poggio \& E. K. Miller: "Integral Equation Solutions of Three-Dimensional Scattering Problems", Computer Techniques for Electromagnetics (Ed. R. Mittra), p. 159 (1973) Pergamon Press

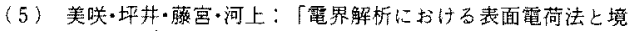
界要素法の計算精度の比較につ62 万人, 電気学会回転稢·静止 器合同研资, RM-84-45：SA-84-16（昭 59)

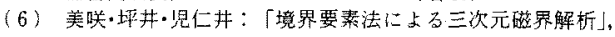
同上, RM-83-7 ; SA-83-7 (昭 58)

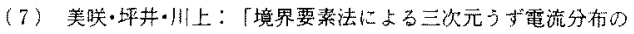
一解析法」, 笔学論 A, 105, 533 (昭 60-10)

(8) H. Tsuboi \& T. Misaki : "Three-Dimensional Analysis of Eddy Current Distributions by the Boundary Element Method Using Vector Variables", IEEE Trans. Magnetics. MAG-23, 3044 (1987)

(9) T. Morisue \& M. Fukumi : "3-D Eddy Current Culculation Using the Magnetic Vector Potential", ibid., 24, 106 (1988)

（10）小貫，他：「有限・境界要瑟併用法による䄼証モデルの解 析」, 雷気学会静止器・回転機合同研資, SA-87-12:RM-87 -23 (昭 62) 
（11）榎園・戸高：「端子電圧を考慮した三次元境界要素磁界解 析」, 同上, SA-88-20：RM-88-42（昭 63）

（12）福見·守末：「積分方程式法による磁界解析」，同上, SA-88 $-16 ; \mathrm{RM}-88-38$ (昭 63)

（13）篠崎・山下・中前：「電界を未知数とする有限一境界要菜法了, 日本シミュレーション学会第 8 回電気・電子工学への有限要 素法の応用シンポジウム, No. 15 (昭 62)

(14) J.A. Stratton:Electromagnetic Theory, p. $250: 468$ (1941) McGraw-Hill

（15）電子通信学会論：電磁界の近代解析法, p. 1 (昭 54）電子通 信学会

（16）石橋：「境界要素法による高周波誘導加熱時のうず電流解 析」, 電学論 B, 104, 149 (昭 59-3)

（17）福見・守末：「磁界解析の際の接合条件の近似法と愦差の関 係」, 同上 A, 108, 558 (昭 63-12)

（18）美咲·坪井·位高・原：「表面電荷法による一般三次元電界の 一解析法とその応用」, 同上 A, 101, 499 (昭 56-10)

(19) T. Misaki \& H. Tsuboi: "Techniques for Boundary Element Analysis of Three-Dimensional Eddy Current Distribution", IEEE Trans. Magnetics, 24, 146 (1988)

(20) H. Tsuboi \& M. Tanaka: "External Conditions for the Vector Potential in the Boundary Element Method", IEEE Trans. Magnetics, 25, 4138 (1989)

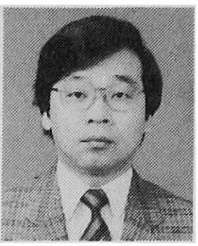

坪 井 始 (正員)

昭和 27 年 4 月 23 日生。 53 年 3 月岡山大学大学院工学研究科電気工 学専攻修士課程修了。同年 4 月同大 学工学部電気工学科(現, 電気電子 工学科)助手, 61 年 7 月同助教授, 現在に至る。工学 博士。主として, 電子計算機による電磁界解析とその 電気・電子機器の最適設計への応用に関する研究に従 事。電子情報通信学会, 情報処理学会, IEEE, 境界 要素法研究会会員。

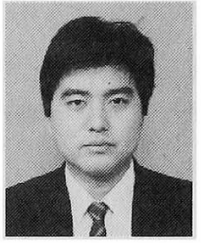

田 中 始 男 (准員)

昭和 39 年 8 月 11 日生。平成元年 3 月岡山大学大学院工学研究科電気 工学専攻修士課程修了。同年 4 月福 山大学工学部情報処理工学科助手, 現在に至る。主として, 境界要素法による電磁界解析 に関する研究に従事。 